\title{
PERAN PROSES PEMBELAJARAN DALAM PENGEMBANGAN KAPABILITAS MANUFAKTUR SKALA MENENGAH DAN BESAR DI JAWA TIMUR
}

\author{
Lena Ellitan (lena.ellitan@yahoo.com) \\ Fakultas Bisnis Universitas Katholik Widya Mandala Surabaya
}

\begin{abstract}
This study examines manufacturing capabilities from the perspective of resource-based view of the firm. It explores the role and capabilities in manufacturing firms that cannot be easily duplicated. Such resources and capabilities in manufacturing firms are formed by employees' internal learning based on cross training and suggestion system, external learning from customer and suppliers, and proprietary processes and equipment developed by the firms. Based on data from 38 manufacturing firms in East Java, the paper empirically demonstrated that competitive advantage in manufacturing result from proprietary processes and equipment which, in turn, is driven by external and internal learning. In other words this study found that (1). Greater internal learning leads to more proprietary processes and equipment. (2) Greater internal learning leads to more proprietary processes and equipment (3). Greater proprietary process and equipment leads to higher competitive manufacturing performance. (4). The alignment between proprietary process and equipment and the manufacturing strategy leads to maximum competitive advantage.
\end{abstract}

Keywords: Internal Learning, External Learning, Proprietary Process and Equipment, Manufacturing Strategy, Manufacturing Performance, East Java Manufacturing Firms.

\section{PENDAHULUAN}

\section{Latar Belakang Masalah}

Perkembangan industri dan perekonomian global membawa dampak pada perubahan paradigma perekonomian dunia, dimana industrialisasi memiliki peran penting dalam menjaga stabilitas perekonomian suatu negara. Sebagai motor penggerak perekonomian, pembangunan industri perlu terus didorong untuk meningkatkan perannya dalam memberi kan kontribusi yang berarti terhadap pembangunan nasional. Mengingat perannya yang strategis, sektor industri khususnya industri manufaktur, perlu ditingkatkan kinerjanya sehingga tidak hanya memiliki daya saing tinggi di pasar lokal tetapi juga internasional. Hal ini menjadi agenda penting pemerintah dan sektor riil dalam mewujudkan strategi pembangunan industri di masa depan, yaitu membangun daya saing industri manufaktur yang berkelanjutan di pasar internasional.

Dalam upaya mencapai keunggulan kompetitif berkelanjutan perlu kemauan dan upaya keras perusahaan untuk mengubah dan menerapkan perspektif dalam proses manufaktur baru dari konsep corporate management menjadi individual self management dan dari process content of strategy menjadi day to day operations. Keunggulan kompetitif diperoleh jika suatu perusahaan dapat memperoleh dan mengembangkan sumber daya manusia dengan lebih cepat dan menerapkan pengetahuannya dengan lebih efektif daripada pesaingnya (Hamel dan Prahalad, 1989). Untuk itu, perusahaan perlu menerapkan strategi yang fleksibel terhadap perkembangan dan perubahan yang terjadi sehingga kapabilitas manufaktur dalam mengelola dan memanfaatkan sumber daya yang terbatas menjadi syarat mutlak bagi perusahaan untuk tetap bertahan hidup dan mencapai kompetitif. Strategi berbasis sumber daya (a resource-based view of strategy) memberikan solusi bagi perusahaan untuk meraih keunggulan kompetitif secara terus menerus melalui sekumpulan sumber daya unik yang dimiliki perusahaan. 
Strategi berbasis sumber daya dalam konsep strategi ini didefinisikan sebagai sumber daya dan kapabilitas yang dimiliki oleh perusahaan yang berbeda dengan perusahaan lain dan memiliki keunggulan khusus dalam jangka panjang (Barney, 1991; Rumelt, 1984; Wernerfelt, 1984 dalam Chuang, 2004). Strategi ini memfokuskan pada sumber daya spesifik perusahaan lebih daripada struktur industri dan strategi untuk mengeksploitasi keunggulan kompetitif (Oetzel, 2004). Konsep ini juga menekankan pada kenyataan bahwa sistem organisasi yang kompleks yang merupakan basis untuk keunggulan kompetitif yang diderivasi dari latar belakang atau sejarah perusahaan. Sebaliknya, konsep keunggulan kompetitif menekankan pada pengembangan konsep cost leadership yang berkaitan dengan upaya pencapaian biaya rendah yang memungkinkan perusahaan untuk dapat menggunakan biaya dan diferensiasi relatif terhadap pesaing dan volume penjualan yang tinggi dengan menciptakan loyalitas merek dan reputasi positif. Secara umum, tujuan pendekatan atau strategi berbasis sumber daya adalah untuk memperbaiki kapabilitas sumber daya guna mencapai kesesuaian stratejik antara sumber daya dan peluang yang efektif.

Peran strategi berbasis sumber daya dalam meningkatkan kinerja perusahaan, khususnya untuk mencapai keunggulan kompetitif, menarik minat peneliti maupun praktisi untuk meneliti implementasi strategi berbasis sumber daya dan pengaruhnya terhadap kinerja perusahaan dan pencapaian keunggulan kompetitif perusahaan. Beberapa penelitian terkait diantaranya dilakukan oleh Hayes dan Wheelright (1978); Swamidass dan Newel (1987); Schroeder, Bates, dan Junttila (2002). Peran penting kapabilitas manufaktur pada penentuan posisi bersaing perusahaan dalam pasar, dan pentingnya kepemilikan proses dan peralatan merupakan kunci utama yang akan membawa pada pencapaian keunggulan kompetitif perusahaan (Hayes dan Wheelright, 1978). Hasil studi yang dilakukan Swamidass dan Newel (1987) menyimpulkan bahwa kapabilitas dan kompetensi merupakan komponen penting kapabilitas organisasi dalam mencapai biaya rendah, fleksibilitas tinggi, dan kualitas tinggi sehingga peran proses manufaktur sebagai sumber daya potensial, penentuan peran manusia dalam aktivitas organisasi dan faktor-faktor organisasional merupakan faktor penting dalam pencapaian keunggulan kompetitif perusahaan.

Penelitian terkait dengan penelitian-penelitian tersebut yang memfokus-kan pada implementasi strategi berbasis sumber daya dilakukan oleh Schroeder, Bates, dan Junttila (2002). Mereka mengembangkan suatu model konseptual strategi manufaktur berbasis sumber daya dan mengemukakan bahwa konsep pembelajaran dalam perusahaan dikembangkan berdasarkan pandangan berbasis sumber daya yang memfokuskan pada pengetahuan kausal, ambiguitas, dan faktor sosial yang kompleks. Melalui proses pembelajaran internal maupun eksternal diharapkan perusahaan memiliki hak patent atas proses dan peralatan yang memberikan keunggulan kompetitif bagi perusahaan. Pembelajaran internal mencakup pelatihan multifungsional bagi pekerja dan memberdayakan pekerja dalam proses dan pengembangan produksi, sehingga diharapkan praktek tersebut membawa organisasi untuk lebih adaptif (Gerwin dan Kolodny, 1992; Hall, 1987 dikutip dalam Schroeder, Bates, dan Junttila, 2002). pembelajaran eksternal dalam konteks perusahaan manufaktur, merupakan proses pembelajaran interorganisasional melalui pemecahan masalah yang timbul dalam interaksi dengan konsumen maupun pemasok yang menciptakan tacit knowledge yang tidak mudah ditiru. peralatan yang dilindungi dengan patent dan peralatan yang dirahasiakan, state of the art equipment dan proses yang telah dikembangkan secara eksklusif oleh perusahaan. Keunggulan kompetitif perusahaan dapat diukur atau dinilai melalui kinerja perusahaan.

Penelitian ini dilakukan dilakukan untuk menguji apakah model konseptual strategi manufaktur berbasis sumber daya, tersebut relevan jika diaplikasikan dalam setting penelitian pada perusahaan-perusahaan manufaktur Indonesia, khususnya di propinsi Jawa Timur. Perusahaan manufaktur di Indonesia pada umumnya dihadapkan pada tantangan persaingan global yang menuntut perusahaan untuk mampu melakukan efisiensi biaya dan diferensiasi produk. Hal ini dikarenakan Era globalisasi ekonomi yang disertai dengan 
pesatnya perkembangan teknologi, berdampak sangat ketatnya persaingan dan cepatnya terjadi perubahan lingkungan usaha. keadaan tersebut merupakan tantangan dan kenyataan yang harus bisa dihadapi serta harus menjadi pertimbangan yang menentukan dalam setiap kebijakan yang akan diimplementasikan, sekaligus merupakan paradigma baru yang harus dihadapi dalam melaksanakan proses industrialisasi. Kemampuan produksi dilandaskan pada kemampuan menciptakan barang dan jasa yang laku di seluruh dunia dalam arti mampu bersaing secara global dan mampu memanfaatkan perkembangan teknologi. Kondisi ini menuntut perusahaan-perusahaan manufaktur untuk dapat meningkatkan daya saing barang dan jasa yang berbasis sumber daya lokal.

\section{Perumusan Masalah}

Berdasarkan gambaran masalah yang telah dijabarkan dalam latar belakang masalah, maka penelitian ini bertujuan untuk menjawab berbagai masalah sebagai berikut:

1. Apakah pembelajaran internal mempengaruhi kepemilikan proses produksi dan peralatan?

2. Apakah pembelajaran ekternal mempengaruhi kepemilikan proses produksi dan peralatan?

3. Apakah kepemilikan proses dan peralatan mempengaruhi kinerja perusahaan?

4. Apakah strategi manufaktur memoderasi hubungan kepemilikan proses produksi dan kinerja perusahaan?

\section{TINJAUAN KEPUSTAKAAN}

\section{Profil Industri Manufaktur di Jawa Timur}

Struktur perekonomian Jawa Timur menunjukkan pertumbuhan ekonomi banyak ditopang oleh kegiatan konsumtif dan buka investasi yang produktif. Hal ini mengakibatkan pertumbuhan ekonomi menunjukkan struktur perekonomian daerah yang kuat, kurang menciptakan nilai tambah dan memicu peningkatan inflasi. Untuk menciptakan pertumbuhan yang berkualitas dan berkelanjutan, perekonomian di Jawa Timur perlu didukung oleh kegiatan investasi di sektor produktif dan jasa, khususnya investasi swasta. Di sektor PRDB (Pendapatan Regional Domestik Bruto) menunjukkan terjadinya pergeseran yaitu berkurangnya sektor-sektor tradeables (listrik, gas dan air, konstruksi, perdagangan, hotel rumah makan, transportasi, kevangan, dan jasa) sehingga bisa disimpulkan bahwa pertumbuhan ekonomi lebih banyak dipicu oleh pertumbuhan PRDB yang nontrables.

Secara umum kinerja perekonomian Jawa Timur telah menunjukkan transformasi struktur perekonomian dari struktur primer ke sekunder tetapi masih semu karena belum diikuti oleh mobilitas tenaga kerja dari sektor primer ke sekunder. Pembangunan industri dan perdagangan adalah bagian dari pembangunan daerah dan pembangunan nasional sehingga pembangunan industri dan perdagangan harus mampu memberikan sumbangan yang berarti terhadap pembangunan industri dan perdagangan di masa depan dalam jangka panjang dan jangka pendek bukan hanya dutujukan untuk mengatasi permasalahan dan kelemahan sector industri dan perdagangan saja yang disebabkan oleh melemahnya daya saing, tapi juga mengatasi permasalahan nasional dan permasalahan yang timbul di daerah.

Di sektor perekonomian Jawa Timur mencanangkan visi 2025 "Jawa Timur sebagai pusat Agribisnis terkemuka berdaya saing global dan berkelanjutan." Penetapan sebagai pusat agribisnis bukan berarti mematikan sector-sektor yang lain, karena pada bulan 2008, ekspor komoditi non migas mencapai 1.074 milliar Dollar AS, kondisi naik 0,76\% dibandingkan dengan bulan Juni 2008 yang mencapai 1.038 milliar Dollar AS. Tembaga menjadi urutan ekspor pertama terbesar senilai 160.457 juta Dollar AS, diikuti kertas dan karton pada peringkat kedua senilai 91.247 juta Dollar AS dan ketiga produk bahan kimia organic (HS 29) 
dengan nilai 79.314 juta Dollar AS. Dari 33 propinsi di Indonesia, ekspor non migas menempati urutan ketiga setelah DKI Jakarta dan Riau.

Pembangunan sector industri manufaktur, kebijakan yang berorientasi spasial dan regional merupakan salah satu faktor kunci yang dapat mendukung pemerintah pusat dan daerah dalam merumuskan dan mengimplementasikan pembangunan (Kuncoro, 2002). Fenomena konsentrasi spasial juga terjadi di Jawa Timur, dimana terdapat berbagai macam konsentrasi spasial pada industri manufaktur. Industri manufaktur terkonsentrasi di kota-kota Surabaya, Malang, Mojokerto, Gresik, Pasuruan, Sidoarjo, Surabaya, Malang memberikan kontribusi 50\% dari output sector industri manufaktur di Jawa Timur. Selain itu industri manufaktur di Jawa timur terkonsentrasi di Kediri dan Jember.

Industri manufaktur di Jawa Timur menyumbang sekitar $20 \%$ dari nilai tambah yang dihasilkan oleh sector industri manufaktur di Indonesia. Surabaya sebagai ibukota propinsi memiliki keterkaitan kota dan daerah pendukung yang tinggi dan terlihat dari: a) a. akses internasional dan ekonomi Surabaya berpengaruh pada wilayah penyangga, b. Surabaya menjadi Growth Pole bagi pembangunan wilayah penyangga karena memiliki akses pelabuhan jalur kereta api dan bandara yang mendukung industri manufaktur di Jawa Timur.

Pada sektor industri manufaktur, Surabaya memberi kontribusi terbesar $18 \%$ dari tenaga kerja industri manufaktur dan 19\% dari output industri manufaktur. Sejak 2006, model yang dianut propinsi Jawa Timur adalah dual track strategi, yaitu di satu sisi berupaya mewujudkan pertumbuhan ekonomi yang berkualitas dan berkesinambungan, disisi lain mendukung terpenuhinya kebutuhan dasar rakyat seperti hak atas pangan, pelayanan kesehatan, hak pendidikan, hak atasd air bersih, sanitasi, dan fasilitas lain. Secara keseluruhan dapat disimpulkan potensi perekonomian Jawa Timur meliputi pertanian, tanaman pangan, hortikultura, perikanan, perkebunan, peternakan, kehutanan, manufaktur, pertambangan, pariwisata, konstruksi, listrik, telekomunikasi, gas air minum, pwerdangangan luar negeri dan dalam negeri, hotel, restoran, dan jasa-jasa.

\section{Pembelajaran Internal dan Eksternal}

Alegre dan Chiva (2008) mendefinisikan pembelajaran organisasional (organizational learning) sebagai proses yang dilakukan oleh perusahaan untuk melakukan pembelajaran. Proses ini terkait dengan perubahan-perubahan yang terjadi dalam struktur dan pengelolaan perusahaan untuk mempertahankan atau memperbaiki kinerja perusahaan secara keseluruhan. Tidak sedikit studi empiris yang dilakukan menekankan pada pentingnya proses pembelajaran dalam organisasi dan bagaimana proses pembelajaran tersebut dilakukan (Bruton et al., 2004). Pentingya peran proses pembelajaran dalam organisasi, dalam hal orientasi pembelajaran, kapabilitas pembelajaran, dan organisasi pembelajar, dalam semua aktivitas bisnis datau kinerja perusahaan telah terdokumentasi dalam literatur manajemen strategi, khususnya dalam hal strategi manufaktur (Calantone et al., 2002; Prieto dan Revilla, 2006). Pembelajaran dalam organisasi telah diakui faktor kunci untuk meningkatkan kinerja dan kapabilitas perusahaan, dan kemampuan untuk belajar baik melalui sumber yang didapat dari dalam (pembelajaran internal) maupun luar (pembelajaran eksternal) perusahaan menjadi sumber untuk menciptakan keunggulan kompetitif perusahaan (Jiang dan Li, 2008).

Konsep pembelajaran dalam perusahaan dikembangkan berdasarkan pandangan berbasis sumber daya yang memfokuskan pada pengetahuan kausal, ambiguitas, dan faktor sosial yang kompleks Pembelajaran internal mencakup pelatihan multifungsional bagi pekerja dan memberdayakan pekerja dalam proses dan pengembangan produksi, sehingga diharapkan praktek tersebut membawa organisasi untuk lebih adaptif (Gerwin dan Kolodny, 1992; Hall, 1987 dikutip dalam Schroeder, Bates, dan Junttila, 2002). Fokus pembelajaran dan kinerja perusahaan memiliki hubungan positif. Menurut Prusak (1997) dikutip dalam 
Schroeder, Bates, dan Junttila (2002), proses pembelajaran merupakan satu-satunya sumber keunggulan kompetitif yang berkelanjutan. Proses pembelajaran bisa terjadi dalam cara yang tidak dapat diprediksi dan berisiko, bahkan kadang-kadang terjadi dalam cara yang sulit dikodifikasikan, yang membawa pada penyebaran sumber daya yang memiliki dampak causally ambiguous.

Nelson dan Winter, 1982; Teece et al., 1997 dikutip dalam Schroeder, Bates, dan Junttila, (2002) mengemukakan bahwa pembelajaran eksternal dalam konteks perusahaan manufaktur, merupakan proses pembelajaran interorganisasional melalui pemecahan masalah yang timbul dalam interaksi dengan konsumen maupun pemasok yang dapat menciptakan tacit knowledge yang tidak mudah ditiru. Pembelajaran eksternal bisa berupa input pemasok dalam produk baru atau desain proses dan keterlibatan pemasok dalam penciptaan kualitas dan perbaikan secara kontinu dan rutin.

Pembelajaran internal mencakup pelatihan multifungsional bagi pekerja dan memberdayakan pekerja dalam proses dan pengembangan produksi, sehingga diharapkan praktek tersebut membawa organisasi untuk lebih adaptif (Liao et al., 2008). Pembelajaran eksternal dalam konteks perusahaan manufaktur, merupakan proses pembelajaran interorganisasional melalui pemecahan masalah yang timbul dalam interaksi dengan konsumen maupun pemasok yang dapat menciptakan tacit knowledge yang tidak mudah ditiru (Almeida et al., 2003). Melalui proses pembelajaran internal maupun eksternal diharapkan perusahaan memiliki hak patent atas proses dan peralatan yang memberikan keunggulan kompetitif bagi perusahaan. Keunggulan kompetitif perusahaan dapat diukur atau dinilai melalui kinerja perusahaan.

St. John dan Harrison, 1999 dikutip dalam Schroeder, Bates, dan Junttila (2002) mengemukakan bahwa kapabilitas dalam pembelajaran organisasi seharusnya menghasilkan proses manufaktur (idiosyncratic manufacturing process), termasuk teknologi proses yang tepat yang memberikan kontribusi pada pencapaian keunggulan kompetitif. Oleh karena itu, dalam penelitian ini difokuskan pada penilaian proses produksi perusahaan sebagai suatu keseluruhan yang kompetitif, dan tingkat kesesuaian proses produksi. Kepemilikan proses produksi dan peralatan mencakup peralatan yang dilindungi dengan patent dan peralatan yang dirahasiakan, state of the art equipment dan proses yang telah dikembangkan secara eksklusif oleh perusahaan.

\section{Hla: Pembelajaran internal mempengaruhi kepemilikan proses produksi \& peralatan HIb: Pembelajaran ekternal mempengaruhi kepemilikan proses produksi \& peralatan}

\section{Kepemilikan Proses Produksi dan Peralatan (Kapabilitas Manufaktur) dan Kinerja Perusahaan}

Berbagai penelitian tentang kontribusi strategi terhadap peningkatan kinerja perusahaan telah dilakukan oleh beberapa peneliti. Hayes dan Wheelright (1978) menyatakan bahwa kapabilitas manufaktur memainkan peran penting pada bagaimana perusahaan bersaing dalam pasar produk dan bagaimana perusahaan harus mengembangkan kapabilitas. Kepemilikan proses dan peralatan merupakan kunci utama yang akan membawa pada pencapaian keunggulan kompetitif perusahaan. Swamidass dan Newel (1987) menyimpulkan bahwa kapabilitas dan kompetensi berdasarkan proses inovasi manufaktur yang spesifik merupakan komponen penting kapabilitas organisasi dalam mencapai biaya rendah, fleksibilitas tinggi, dan kualitas tinggi. Dalam hal ini peran proses manufaktur sebagai sumber daya potensial, penentuan peran manusia dalam aktivitas organisasi dan faktorfaktor organisasional merupakan faktor penting dalam pencapaian keunggulan kompetitif perusahaan.

Ferdows dan De Meyer dikutip dalam Schroeder, Bates, dan Junttila (2002) melakukan suatu studi yang memfokuskan pada proses produksi dengan pengembangan sekelompok kapabilitas perusahaan untuk mencapai perbaikan kinerja perusahaan. Sedangkan Flynn 
dan Schroeder (1994) mengemukakan adanya keterkaitan antara praktek manajemen kualitas, JIT, strategi manufaktur, dan kinerja perusahaan. Penelitian-penelitian tersebut berbeda dengan konsep pandangan berbasis sumber daya karena pada penelitianpenelitian tentang strategi manufaktur biasanya menyelidiki adopsi praktek-praktek manufaktur khusus dan bagaimana pengaruhnya terhadap kinerja perusahaan.

Schroeder, Bates, dan Junttila (2002) mengembangkan suatu model konseptual strategi manufaktur berbasis sumber daya dan mengemukakan bahwa konsep pembelajaran dalam perusahaan dikembangkan berdasarkan pandangan berbasis sumber daya yang memfokuskan pada pengetahuan kausal, ambiguitas, dan faktor sosial yang kompleks. Menurut Collins dan Montgomery (1995) dalam Paiva et al. (2008), pandangan berbasis sumber daya dikembangkan berdasarkan kombinasi perspekstif pembelajaran internal dan eksternal yang berkaitan erat dengan pendekatan tradisional dalam implementasi strategi. Pendekatan ini menekankan pada kemampuan perusahaan untuk menjelaskan secara detail dan jelas baik dalam hal manejerial, paktik, pengembangan daya saing, profitabilitas perusahaan, dan kompetensi inti perusahaan.

Kapabilitas manufaktur yang menentukan keunggulan kompetitif suatu perusahaan diukur melalui kinerja perusahaan. Banyak faktor eksternal perusahaan dapat mengubah pengaruh sumber daya dalam proses produksi terhadap ukuran kinerja finansial seperti penjualan dan kemampulabaan perusahaan. Dalam penelitian ini digunakan indeks pengukuran beberapa variabel kinerja yaitu biaya yang mewakili persentase penjualan, kualitas yang sesuai, persentasi pengiriman tepat waktu siklus waktu dari penerimaan bahan mentah sampai penerimaan pada konsumen, dan panjangnya waktu atau jadwal produksi. Hayes dan Wheelwright (1984) dikutip dalam Schroeder, Bates, dan Junttila (2002) mengemukakan bahwa pengembangan kepemilikan proses dan peralatan membawa pada keunggulan kompetitif melalui pencapaian kinerja perusahaan yang baik. Variabel kinerja perusahaan terdiri atas empat dimensi pengukuran kinerja yang mencakup kualitas, pengiriman, fleksibilitas, dan kos.

Kualitas memfokuskan pada pentingnya memproduksi produk dan jasa yang dapat memuaskan spesifikasi dan kebutuhan konsumen. Oleh karena itu, perusahaan perlu memperhatikan masalah perbaikan kualitas sehingga dapat mengurangi biaya produksi, karena dengan melakukan sesuatu dengan benar saat pertama kali barang dan jasa diproduksi dapat mengeliminasi "waste." Perbaikan kualitas merupakan salah satu cara bagi organisasi untuk memperbaiki kinerja bisnis (Ward et al., 1995). Fleksibilitas merupakan kemampuan untuk merespon perubahan cepat baik perubahan produk, jasa, maupun proses. Fleksibilitas manufaktur didefinisikan sebagai kemampuan perusahaan manufaktur untuk mengalokasikan dan mengalokasikan kembali sumber daya yang dimiliki secara efektif dalam merespon perubahan lingkungan dan kondisi internal (Gerwin, 1993). Sedangkan Braglia dan Petroni (2000) menyatakan bahwa fleksibilitas mencakup mesin, proses, produk, volume, dan lay out.

Pengiriman meliputi kemampuan dalam merespon pemesanan konsumen. Leong et al. (1990) mendefinisikan strategi pengiriman sebagai kemampuan pengiriman (dengan memenuhi jadwal pengiriman maupun janji pengiriman) dan kecepatan pengiriman (bertindak cepat atas pemesanan konsumen). Pengukuran kinerja pengiriman menekankan pada aktifitas yang memfokuskan pada peningkatan reliabilitas pengiriman misalnya pengiriman yang tepat waktu, akurasi dalam status persediaan, dan waktu tunggu pengiriman. Strategi biaya sebagai produksi dan distribusi produk dengan biaya terendah dan sumber daya terbuang (waste resource) yang minimum. Strategi kualitas didefinisikan sebagai aktivitas perusahaan untuk memproduksi produk yang sesuai dengan spesifikasi atau memenuhi kebutuhan konsumen. Harga yang lebih rendah dapat meningkatkan permintaan produk atau jasa tapi juga mengurangi margin profit jika produk atau jasa tidak dapat diproduksi pada harga yang lebih rendah. Untuk dapat bersaing dalam lingkungan bisnis dengan berbasis pada biaya, seorang manajer operasi perlu menawarkan produk dan 
jasa pada biaya per unit yang rendah baik biaya tenaga kerja, material, scrap, maupun biaya overhead lainnya.

\section{H2: Kepemilikan peralatan proses produksi dan teknologi mempengaruhi kinerja perusahaan.}

\section{Efek Moderasi Strategi Manufaktur}

Literatur-literatur dalam manajemen teknologi dan sumber daya menunjukkan bahwa sumber daya harus di selaraskan dengan strategi manufaktur untuk keunggulan kompetitif mereka (Skinner, 1974; Buffa, 1984; Burgess, et al., 1998; Cagliano dan Spigna, 2000; Gordon dan Sohal, 2001, Ellitan, 2004i). Skinner (1969) menyatakan bahwa prioritas strategik yang lebih luas hanya dapat dicapai dengan menggunakan teknologi manufaktur. Buffa (1984) menyatakan bahwa perusahaan Jepang telah memimpin banyak industri melalui integrasi strategi manufaktur dengan teknologi yang tepat. Perusahaan perlu mengambil tindakan untuk memperbaiki kinerja proses melalui adopsi inovasi proses yang sesuai dengan prioritas kompetitif mereka (Ellitan, 2004i; Cagliano dan Spina, 2000; Burgess, et al., 1998). Ellitan (2004i) juga menemukan bahwa perusahaan yang memiliki prioritas kompetitif, mengadopsi, dan mengimplementasikan hard (teknologi berbasis computer, teknologi manufaktur maju, dan peralatan manufaktur) dan soft technology (adopsi praktik pengurangan waktu produksi, praktik manajemen kualitas, dan teknik pengembangan proses) lebih sukses.

Currie and Seddon (1993) mengemukakan bahwa ketiadaan strategi manufaktur dalam proses produksi tidak akan menjamin kesuksesan operasi perusahaan. Ellitan (2004) mengemukakan bahwa teknologi sendiri tidak dapat memberikan keunggulan kompetitif karena teknologi ada pada semua perusahaan dalam industri. Perusahaan harus mengembangkan mekanisme integratif yang unik untuk setiap organisasi. Dean and Snell (1996) menemukan bahwa kesesuaian antara prioritas strategic perusahaan dan penggunaan teknologi manufaktur maju, ketersediaan bahan baku dan sumber daya, dan praktik manajemen ditentukan oleh apakah sumber daya tersebut memiliki dampak positif atau negatif terhadap kinerja. Misalnya, AMT sangat sesuai dengan strategi fleksibilitas, tetapi tidak dengan strategi biaya (Jaikumar, 1986; Parasarthy \& Sethi 1992, Ellitan, 2003d). Mereka berpendapat bahwa jika perusahaan lebih menekankan strategi biaya, AMT tidak akan digunakan scara potensial karena kapabilitas untuk menciptakan produksi fleksibel akan tidak bermanfaat. Sebaliknya, Corbett and Van Wassenhove (1993) mengemukakan bahwa dalam beberapa kasus AMT harus didukung dengan usaha untuk mengurangi biaya produksi. Hal ini berarti bahwa adopsi AMT sesuai dengan strategi biaya, dan penekanan tertinggi dalam biaya strategi akan memperkuat pengaruh AMT terhadap kinerja perusahaan.

Praktik-praktik manajemen akan lebih efektif jika didukung dengan strategi manufaktur yang menekankan pada kualitas dan fleksibilitas. Hal ini dimungkinkan untuk menyatakan bahwa praktik-praktik manajemen dapat memperbaiki kualitas dan fleksibilitas operasi. Posisi ini menyatakan bahwa pendekatan strategik untuk dapat meraih keuntungan dan konsisten dengan soft technology. Berdasarkan literatur yang ada, strategi manufaktur harus dipandang sebagai moderator potensial dalam hubungan sumber daya dan kinerja perusahaan. Studi yang lakukan oleh Ellitan (2002) membuktikan bahwa keselarasan antara teknologi dan strategi manufaktur diperlukan untuk mencapai kineja maksimum. Strategi manufaktur yang tepat akan memperkuat pengaruh teknologi pada kinerja perusahaan (Ellitan, 2004), sehingga dalam studi ini diformulasikan sebuah proposisi sebagai berikut:

\section{$\mathrm{H}_{3}$ : Pengaruh sumber daya terhadap kinerja perusahaan dimoderasi oleh strategi manufaktur yang diterapkan (penekanan terhadap strategi manufaktur)}




\section{Kerangka Penelitian}

Studi ini memfokuskan pada strategi manufaktur yang didefinisikan sebagai kapabilitas dan sumber daya dan hubungannya dengan kinerja organisasi. Ada tiga faktor atau tipe sumber daya dan kapabilitas yang dikembangkan dalam fungsi produksi yang sulit ditiru dan ditransfer (St. John dan Harrison, 1999 dikutip dalam Schroeder, Bates, dan Junttila (2002) yaitu proprietary process and equipment, internal learning, dan external learning. Praktik manufaktur diadopsi dengan meniru "world class manufactures" yang dapat memberikan kontribusi bagi keseimbangan kompetitif tapi tidak untuk keunggulan kompetitif. Model ini juga menekankan bahwa peran pembelajaran dan pengembangan pengetahuan dalam perusahaan adalah untuk menghasilkan proses dan peralatan yang diciptakan melalui proses "path dependent problem solving" yang memediasi antara proses pembelajaran dan kinerja perusahaan. Model penelitian digambarkan dalam Gambar 1.

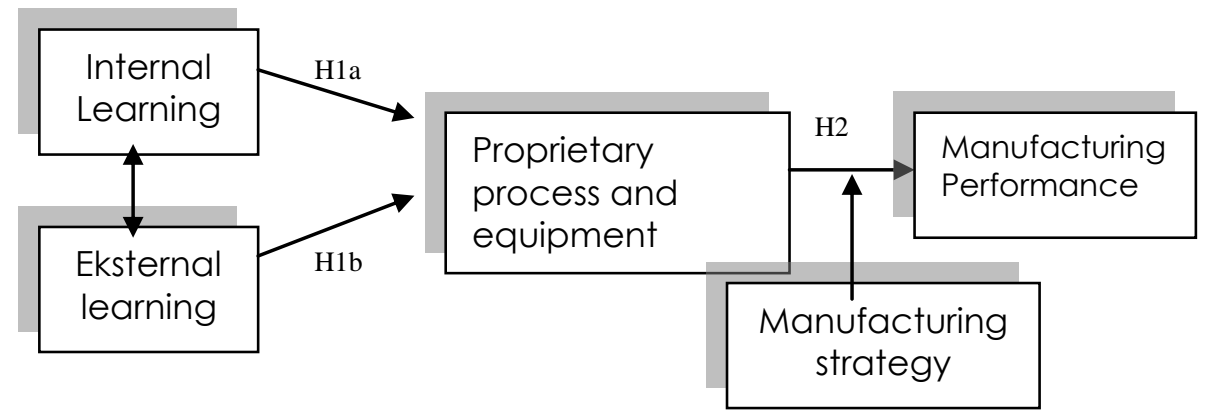

Gambar 1. Model Penelitian

Sumber: Schroeder, Bates, dan Junttila, 2002 dan Modifikasi Peneliti

\section{METODE PENELITIAN}

\section{Desain Penelitian}

Penelitian ini merupakan studi empiris yang bertujuan menguji hubungan antara beberapa variabel independent dengan beberapa variabel independent. Variabel-variabel independen penelitian ini meliputi tingkat pembelajaran internal dan eksternal organisasi, sementara variabel dependennya adalah kinerja operasional perusahaan secara relatif dibandingkan kompetitor dan pertumbuhan perusahaan. Tingkat kepemilikan peralatan produksi merupakan variabel antara dalam penelitian ini dan strategi manufaktur sebagai variabel moderator yang mempengaruhi hubungan kepemilikan peralatan produksi dan kinerja. Hubungan antara variabel-variabel penelitian ini diuji dengan menggunakan model regresi sederhana, regresi berganda, dan regresi bertingkat.

\section{Populasi dan Sampel}

Populasi penelitian yang menjadi obyek penelitian ini meliputi seluruh perusahaan manufaktur yang beroperasi di Indonesia. Populasi merupakan perusahaan manufaktur yang terdaftar Direktori Perusahaan Manufaktur yang diterbitkan oleh Biro Pusat Statistik, tahun 2006. Sampel ditentukan dengan menggunakan teknik purposive sampling, dan sampel yang dipilih adalah perusahaan manufaktur dengan kriteria yang memiliki skala besar. Jumlah sampel yang dipakai dalam penelitian ini sebesar 100 perusahaan.

Penggolongan perusahaan kecil, sedang dan besar untuk studi ini dilakukan berdasar jumlah tenaga kerja tetap yaitu: (1) Perusahaan kecil: 10-99 orang karyawan. (2) Perusahaan sedang: 100-499 orang karyawan. (3) Perusahaan besar: 500 atau lebih. Penggolongan skala 
perusahaan berdasar pada jumlah karyawan tetap telah dilakukan oleh peneliti terdahulu yaitu Ko, Kinkade, dan Brown, (2000) dan juga Cagliano dan Spina (2000). Berdasar kriteria ini maka yang diambil sebagai sampel adalah perusahaan manufaktur yang memiliki tenaga kerja tetap lebih dari 500 orang.

\section{Teknik Pengumpulan Data}

Data yang digunakan dalam penelitian ini meliputi data primer dan data sekunder. Data primer diperoleh melalui penyebaran kuesioner (mailed questionnaires) dan direct survey (untuk mengantisipasi rendahnya tingkat respon jika data hanya diperoleh melalui mail survey) pada perusahaan-perusahaan manufaktur, dengan pimpinan perusahaan sebagai target subject, disesuaikan dengan kondisi perusahaan manufaktur di Indonesia. Pendistribusian kuesioner dilakukan selama satu bulan dengan batas pengembalian selama enam minggu. Untuk meningkatkan tingkat pengembalian kuesioner peneliti mencoba mengikuti saran yang diajukan oleh Issac dan Michael (1990) yaitu dengan sistem bebas perangko balasan dan pengiriman surat susulan pada responden (dikutip dari Thesis Ellitan, 1998). Data Sekunder terkait dengan pengumpulan data perusahaan manufaktur yang ada di Indonesia. Populasi meliputi seluruh perusahaan manufaktur yang beroperasi, sedangkan sampel diambil berdasarkan perusahaan manufaktur yang terdaftar dalam Direktori Perusahaan Manufaktur yang diterbitkan oleh Biro Pusat Statistik, tahun 2007.

\section{Definisi Operasional dan Pengujian Instrumen}

\section{Pembelajaran Internal}

Konsep pembelajaran dalam perusahaan dikembangkan berdasarkan pandangan berbasis sumber daya yang memfokuskan pada pengetahuan kausal, ambiguitas, dan faktor sosial yang kompleks. Pembelajaran internal mencakup pelatihan multifungsional bagi pekerja dan memberdayakan pekerja dalam proses dan pengembangan produksi, sehingga diharapkan praktek tersebut membawa organisasi untuk lebih adaptif (Gerwin dan Kolodny, 1992; Hall, 1987 dikutip dalam Schroeder, Bates, dan Junttila, 2002). Pembelajaran internal mencakup 8 butir pertanyaan dengan nilai Cronbach Alpha sebesar 0.920.

\section{Pembelajaran Eksternal}

Nelson dan Winter, 1982; Teece et al., 1997 dikutip dalam Schroeder, Bates, dan Junttila, (2002) mengemukakan bahwa pembelajaran eksternal dalam konteks perusahaan manufaktur, merupakan proses pembelajaran interorganisasional melalui pemecahan masalah yang timbul dalam interaksi dengan konsumen maupun pemasok yang menciptakan tacit knowledge yang tidak mudah ditiru. Pembelajaran eksternal mencakup 14 butir pertanyaan tentang hubungan interorganisasional seperti tiga dimensi yang meliputi: kepercayaan terhadap mitra bisnis, komitmen terhadap mitra bisnis, dan sharedvision diantara mitra bisnis..

\section{Kepemilikan Proses Produksi dan Peralatan}

Variabel kepemilikan proses produksi dan peralatan mencakup 14 butir pertanyaan tentang peralatan yang dilindungi dengan patent dan peralatan yang dirahasiakan, state of the art equipment dan proses yang telah dikembangkan secara eksklusif oleh perusahaan.

\section{Strategi manufaktur.}

Strategi manufaktur bisa didefinisikan sebagai penggunaan kekuatan-kekuatan manufaktur sebagai senjata kompetitif untuk mencapai tujuan-tujuan bisnis dan perusahaan (Swamidas and Newwell, 1987). Strategi manufaktur mencerminkan tujuan dan strategi bisnis yang memungkinkan fungsi-fungsi manufaktur untuk memberikan kontribusi yang maksimal untuk 
menciptakan daya saing dan kinerja bisnis dalam jangka panjang (Wheelwright and Hayes, 1985). Strategi manufaktur juga dianggap sebagai prioritas kompetititf perusahaan yang meliputi biaya, kualitas, fleksibilitas, dan penghantaran (Burgess et al., 1998). Stonebaker dan Leong (1994) mendifinisikan strategi biaya sebagai suatu usaha untuk memproduksi dan mendistribusikan produk dengan biaya minimum. Strategi kualitas terkait dengan usaha menghasilkan produk dan jasa sesuai dan melebihi permintaan konsumen (Braglia, dkk., 2000). Strategi fleksibilitas merupakan suatu cara untuk merespon secara cepat perubahan konsumen terhadap produk, proses, dan volume (Gerwin, 1993). Sementara itu, Braglia et al., (2000) mengemukakan bahwa strategi penghantaran meliputi keandalan merespon pesanan konsumen dan penghantaran produk. Untuk mengukur strategi manufaktur yang diterapkan oleh perusahaan, meneliti mengadopsi instrumen yang dikembangkan oleh Badri, et al (2000). Strategi manufaktur diukur dengan menggunakan skala Likert 5 poin $(1=$ sangat tidak penting -5 = sangat penting).

\section{Kinerja Operasi}

Pengukuran kinerja perusahaan digunakan indeks pengukuran beberapa variabel kinerja yaitu biaya yang mewakili persentase penjualan, kualitas yang sesuai, persentasi pengiriman tepat waktu siklus waktu dari penerimaan bahan mentah sampai penerimaan pada konsumen, dan panjangnya waktu atau jadwal produksi. Variabel kinerja perusahaan terdiri atas empat dimensi pengukuran kinerja yang mencakup kualitas (2 pertanyaan), pengiriman ( 3 pertanyaan), fleksibilitas (3 pertanyaan), dan kos (3 pertanyaan). Skala Likert lima poin digunakan untuk mengukur tingkatan persetujuan atau ketidaksetujuan maupun tingkat baik atau jeleknya (pada ukuran kinerja perusahaan) atas statement atau pernyataan yang diajukan item-item pernyataan dalam kuesioner.

\section{Teknik Analisis Data}

Prosedur analisis data yang akan digunakan meliputi beberapa langkah sebagai berikut:

a. Melakukan uji validitas dan reliabilitas. Suatu alat ukur atau instrumen pengukuran dikatakan baik jika memenuhi kriteria yaitu validitas dan reliabel. Uji reliabilitas dilakukan untuk mengestimasi sejauh mana instrumen pengukuran yang digunakan bebas dari kesalahan acak atau tidak stabil, artinya dalam pengujian reliabilitas ini dimaksudkan untuk mengetahui sejauh mana hasil pengukuran terhadap konsistensi jawaban responden. Konsistensi internal item-item pertanyaan dalam kuesioner akan diuji dengan metode Cronbach Alpha. Nilai rule of thumb yang akan digunakan untuk nilai Crobach Alpha harus lebih besar dari 0,7 meskipun nilai 0,6 juga masih dapat diterima (Hair, et al., 1998).

b. Uji Pelanggaran asumsi klasik meliputi uji normalitas, homoscedastisitas, multikolinieritas, dan uji autokorelasi. Pengujian asumsi heteroskedastisitas bertujuan untuk menguji apakah dalam model regresi terjadi ketidaksamaan variance dari residual satu pengamatan ke pengamatan lain. Uji multikolinieritas bertujuan untuk menguji apakah model regresi ditemukan adanya korelasi antar variabel bebas dengan menggunakan nilai VIF (Variance Inflation Factor) dan korelasi antar variabel bebas harus lemah. Uji normalitas bertujuan untuk menguji apakah dalam model regresi variabel pengganggu atau residual memiliki distribusi normal. Uji autokorelasi bertujuan untuk menguji apakah dalam model regresi linier ada autokorelasi antara kesalahan pengganggu pada periode $t$ dengan kesalahan pengganggu pada periode $t-1$ (sebelumnya). Uji autokorelasi dalam penelitian ini menggunakan uji Durbin-Watson (DW test).

c. Pengujian hipotesis dilakukan untuk menguji pengaruh pembelajaran internal dan eksternal terhadap kepemilikan peroses serta pengaruh kepemilikan proses terhadap kinerja perusahaan. Hasil pengujian model dengan menggunakan metode analisis Hierarchycal Regression Analysis. 


\section{ANALISIS DATA}

\section{Tinjauan Umum Data}

\section{Tingkat Respon}

Table 1 menyajikan rangkuman tingkat respon studi ini. Sembilan belas kuesioner yang dikirimkan kembali karena perusahaan dinyatakan tutup atau pindah ke alamat lain yang tidak diketahui. Dua perusahaan menolak berpartisipasi dengan alasan tidak dapat menjawab ataupun memberikan penilaian atas pertanyaan-pertanyaan yang diajukan dalam kuesioner penelitian. Selanjutnya empat perusahaan memberikan jawaban yang tidak lengkap sehingga tidak dapat diikutsertakan dalam analisis data. Akhirnya, Tigapuluh delapan kuesioner digunakan untuk kepentingan studi ini. Response rate sebesar 10,10\% adalah reasonable mengingat responden dalam penelitian ini adalah CEOs atau top manager dalam perusahaan dan batas waktu pengumpulan data yang relatif singkat. Disamping itu peneliti juga tidak mengirimkan surat follow up karena keterbatasan anggaran.

Table 1. Distribusi Kuesioner

\begin{tabular}{|lr|}
\hline Kuesioner yang didistribusikan. & 400 \\
Tidak terkirim/Tutup/Pindah Alamat. & 19 \\
Menolak berpartisipasi & 2 \\
Kembali dan bias diolah. & 38 \\
Kembali dan tidak bias diolah. & 3 \\
Tidak kembali. & 376 \\
Tingkat Respon. & $10.90 \%$ \\
Tingkat Respond yang bisa diolah. & $10.10 \%$ \\
\hline
\end{tabular}

\section{Karakteristik Responden}

Data mengemai profil atau karakteristik responden selengkapnya dapat dilihat di Tabel 2. Mayoritas responden memiliki tenaga kerja tetap antara 100-2000 tenaga kerja, dan hanya 11 responden yang memiliki jumlah tenaga kerja tetap lebih besar dari 2000 orang. Lebih dari $85 \%$ telah beroperasi lebih dari 10 tahun dan terdapat 6 perusahaan yang relatif baru.

Dari keseluruhan responden, $18.4 \%$ perusahaan berasal dari industri logam, permesinan otomotif dan elektronik, $18.4 \%$ mewakili industri kimia, batubara, dan plastik, $10.5 \%$ mewakili industri tekstil, garmen, dan kulit, dan 10.5\%beroperasi dalam bidang kerajinan, rotan, bambu, dan perabot. Selebihnya mewakili industri batubara minyak dan karet. Menurut kepemilikannya, kurang lebih $90 \%$ responden dimiliki oleh orang Indonesia, sementara selebihnya merupakan perusahaan joint venture dan perusahaan asing.

Table 2 Karakteristik Umum Responden

\begin{tabular}{|l|l|l|l|}
\hline Dimensi & Kategori & Jumlah responden & Persentase \\
\hline Umur Perusahaan & Kurang dari lima tahun & 6 & 15.8 \\
\hline & 5-10 tahun & 3 & 7.9 \\
\hline & $>10-20$ tahun & 10 & 26.3 \\
\hline & $>20-30$ tahun & 12 & 31.6 \\
\hline & Lebih dari 30 tahun & 7 & 18.4 \\
\hline Bidang Usaha & $\begin{array}{l}\text { tekstil,pakaian, kulit } \\
\text { kayu,bambu,rotan, kerajinan, } \\
\text { perabot }\end{array}$ & 4 & 10.5 \\
\hline $\begin{array}{l}\text { industri batubara, kimia, minyak, } \\
\text { karet, plastik }\end{array}$ & 6 & 10.5 \\
\hline
\end{tabular}




\begin{tabular}{|l|l|l|l|}
\hline & mineral dan bahan logam & 7 & 18.4 \\
\hline & $\begin{array}{l}\text { barang logam, permesinan, } \\
\text { otomotif,elektronik }\end{array}$ & 7 & 18.4 \\
\hline & & & \\
\hline Pemilik & Lokal & 35 & 92.1 \\
\hline & Asing & 1 & 2.6 \\
\hline & Joint venture & 2 & 5.3 \\
\hline Tenaga kerja & & & 36.8 \\
\hline & $100-999$ & 14 & 34.2 \\
\hline & $1000-1999$ & 13 & 10.5 \\
\hline & $2000-2999$ & 4 & 18.4 \\
\hline
\end{tabular}

\section{Goodness of Measures}

Menurut Huck dan Corner (1996) kualitas data yang dihasilkan dari penggunaan instrumen penelitian dapat dieveluasi melalui uji reliabilitas dan uji validitas. Penelitian ini menggunakan uji konsistensi internal dengan menggunakan koefisien alpha Cronbach. Uji homogenitas data dengan menggunakan uji korelasional antara skor masing masing butir dengan skor total. Seperti yang dikemukakan sebelumnya, reliabilitas data dapat dilihat dengan menghitung koefisien Cronbach's alpha. Pengukuran multi item dianggap reliable jika Cronbach's alpha lebih tinggi dari 0.7 (Nunnaly, 1978). Validitas pengukuran juga dilakukan dengan melakukan Uji homogenitas data yaitu menggunakan uji korelasional antara skor masing masing butir dengan skor total. Semakin tinggi koefisien homogenitas semakin valid dan reliable pengukuran tersebut. Ringkasan uji reliabilitas dan validitas dapat dilihat pada Tabel 3. Hasil studi ini menunjukan semua pengukuran memiliki reliabilitas (lebih dari 0.7$)$ dan validitas yang tinggi.

Tabel 3. Uji Validitas dan Reliabilitas

\begin{tabular}{|l|l|l|l|}
\hline Variabel Penelitian & Jumlah Kuesioner & Reliability & Item homogeneity \\
\hline Pembelajaran internal & 11 & .9177 & $.625-.904$ \\
Pembelajaran eksternal & 11 & .8766 & $.531-.839$ \\
Kepemilikan alat dan teknologi & 4 & .5443 & $.559-.700$ \\
Strategi Biaya & 3 & .8221 & $.840-.892$ \\
Strategi Kualitas & 5 & .8545 & $.730-.882$ \\
Strategi Fleksibilitas & 4 & .7326 & $.711-.804$ \\
Strategi Penghantaran & 5 & .8610 & $.681-.869$ \\
Kinerja operasi & 10 & .8844 & $.589-.799$ \\
\hline
\end{tabular}

\section{Statistik Diskriptif}

Tabel 4 menunjukkan tingkat pembelajaran internal yang dilakukan oleh perusahaanperusahaan manufaktur di Indonesia. Hasil studi ini menunjukkan bahwa tingkat pembelajaran internal yang paling rendah adalah pada pelaksanaan saran atau masukan untuk perbaikan produk dan proses secara serius, sementara pembelajaran internal yang paling tinggi terlihat dari aspek pelatihan kepada karyawan untuk dapat mengerjakan lebih dari satu tugas. Secara umum tingkat pembelajaran internal masih berada pada level rendah (dibawah nilai moderate 2.5).

Table 4: Tingkat Pembelajaran Internal

\begin{tabular}{|l|l|r|}
\hline Internal Learning (Pembelajaran Internal) & Mean & Standard deviation \\
\hline $\begin{array}{l}\text { Melatih karyawan untuk dapat mengisi bagian lain di luar } \\
\text { tanggung jawab mereka jika diperlukan }\end{array}$ & 2.3158 & 1.21043 \\
$\begin{array}{l}\text { Memberikan pelatihan kepada karyawan untuk dapat } \\
\text { mengerjakan lebih dari satu tugas }\end{array}$ & 2.7105 & 1.27147 \\
\hline
\end{tabular}




\begin{tabular}{|c|c|c|}
\hline $\begin{array}{l}\text { Menerima saran/masukan yang berguna dalam } \\
\text { perusahaan }\end{array}$ & 2.5526 & 1.10765 \\
\hline $\begin{array}{l}\text { Melaksanakan saran/masukan untuk perbaikan produk } \\
\text { dan proses secara serius }\end{array}$ & 1.5526 & .86046 \\
\hline $\begin{array}{l}\text { Selalu memperbaharui proses pemeliharaan peralatan } \\
\text { sesuai / lebih baik dari standar industri }\end{array}$ & 2.0000 & 1.01342 \\
\hline $\begin{array}{l}\text { Komitmen tinggi untuk menciptakan lingkungan kerja yang } \\
\text { kondusif melalui penjaminan keselamatan kerja dan } \\
\text { kesejahteraan karyawan }\end{array}$ & 2.3947 & 1.36638 \\
\hline $\begin{array}{l}\text { Mengimplementasikan program-program r untuk } \\
\text { meningkatkan pengetahuan karyawan (seperti } \\
\text { pemberdayaan karyawan dan pembentukan autonomuos } \\
\text { teams) }\end{array}$ & 2.3947 & 1.19773 \\
\hline $\begin{array}{l}\text { Memperbaiki kapasitas manufaktur melalui pembelian } \\
\text { mesin baru, merekrut karyawan baru, pemgembangan } \\
\text { fasilitas produksi }\end{array}$ & 2.5789 & 1.30760 \\
\hline $\begin{array}{l}\text { Melakukan reorganisasi perusahaan melalui implementasi } \\
\text { e-business dan atau e-commerce }\end{array}$ & 2.3947 & 1.17495 \\
\hline Mengimplementasikan program otomatisasi proses produksi & 2.3158 & 1.11756 \\
\hline Mengimplementasikan teknologi informasi dan komunikasi & 2.1842 & 1.22707 \\
\hline Internal Learning (Pembelajaran Internal) & 2.3086 & .87134 \\
\hline
\end{tabular}

Tabel 5 menunjukkan nilai rata-rata tingkat Pembelajaran Eksternal (External Learning). Hasil temuan ini mengindikasikan bahwa rata-rata terendah aspek pembelajaran eksternal adalah pada implementasi program untuk memperbaiki dan mempercepat proses pengembangan produk baru dan restrukturisasi proses pabrikasi dan pengaturan tata letak mesin untuk mendukung proses produksi. Hal ini bukanlah sesuatu yang mengherankan mengingat implementasi program untuk memperbaiki dan mempercepat proses pengembangan produk baru dan restrukturisasi proses pabrikasi dan pengaturan tata letak mesin untuk mendukung proses produksi merupakan aspek pembelajaran eksternal yang memerlukan biaya tinggi namun juga memiliki resiko kegagalan yang cukup besar. Dalam kondisi ketidakpastian lingkungan bisnis, kedua hal ini perlu dilakukan secara hati-hati. Pembelajaran ekternal yang paling tinggi adalah pada aspek melibatkan pelanggan secara aktif dalam proses desain produk. Hal ini wajar dilakukan oleh pelaku bisnis mengingat suara pelanggan penentu kelangsungan hidup perusahaan dan produk mereka di arena persaingan. Secara keseluruhan tingkat pembelajaran eksternal cenderung ada pada level moderate, yang menunjukkan gambaran tipikal negara berkembang.

Tabel 6 menunjukkan nilai rata-rata kepemilikan peralatan dan teknologi. Hasil temuan ini mengindikasikan bahwa kepemilikan peralatan dan teknologi diatas level moderat 3. Tingkat adopsi teknologi proses dalam perusahaan dibandingkan dengan kompetisi industri pada basis global dan Kepemilikan peralatan membantu kami untuk meraih keunggulan kompetitif memiliki nilai tertinggi. Hal ini mengindikasikan peluang untuk meningkatkan kepemilikan peralatan dan teknologi terutama dalam hal kepemilikan peralatan yang diproteksi dengan hak paten perusahaan

Table 5: Tingkat Pembelajaran Eksternal (External Learning)

\begin{tabular}{|l|l|r|}
\hline Tingkat Pembelajaran Eksternal & Mean & Std. Deviation \\
\hline Mengadopsi software ERP (Enterprise Resource Planning) & 3.4474 & 1.03185 \\
\hline Menjaga hubungan jangka panjang dengan pemasok & 3.5789 & .79293 \\
\hline $\begin{array}{l}\text { Memelihara komunikasi yang dekat dengan pemasok tentang } \\
\text { pertimbangan kualitas dan perubahan desain }\end{array}$ & 3.5789 & .97625 \\
\hline $\begin{array}{l}\text { Memberikan umpan balik tentang kualitas dan kinerja } \\
\text { pengiriman kepada pelanggan. }\end{array}$ & 3.1579 & .88612 \\
\hline $\begin{array}{l}\text { Pelanggan kami secara aktif dilibatkan dalam proses desain } \\
\text { produk }\end{array}$ & 3.8947 & .64889 \\
\hline
\end{tabular}




\begin{tabular}{|l|l|r|}
\hline $\begin{array}{l}\text { Melakukan restrukturisasi strategi perusahaan dan mengelola } \\
\text { portofolio terkait dengan pemasok }\end{array}$ & 3.6579 & .66886 \\
\hline $\begin{array}{l}\text { Memusatkan perhatian pada aktivitas inti dan outsourcing untuk } \\
\text { mendukung proses dan aktivitas operasi (pemeliharaan mesin } \\
\text { dan peralatan, penanganan material) }\end{array}$ & 3.6579 & .87846 \\
\hline $\begin{array}{l}\text { Melakukan restrukturisasi proses pabrikasi dan pengaturan tata } \\
\text { letak mesin untuk mendukung proses produksi }\end{array}$ & 3.0526 & 1.08919 \\
\hline $\begin{array}{l}\text { Mengimplementasikan program perbaikan kualitas secara } \\
\text { kontinu (seperti manajemen kualitas terpadu, six sigma) }\end{array}$ & 3.2895 & .86705 \\
\hline $\begin{array}{l}\text { Mengimplementasikan program perbaikan produktivitas } \\
\text { peralatan (seperti program TPM/ Total Productive Maintenance) }\end{array}$ & 3.3684 & .78572 \\
\hline $\begin{array}{l}\text { Mengimplementasikan program untuk memperbaiki dan } \\
\text { mempercepat proses pengembang-an produk baru }\end{array}$ & 3.0263 & .94402 \\
\hline Tingkat Pembelajaran Eksternal (External Learning) & 3.4282 & .58874 \\
\hline
\end{tabular}

Tabel 6. Kepemilikan Peralatan dan Teknologi

\begin{tabular}{|l|l|l|r|}
\hline Kepemilikan Peralatan dan Teknologi & Mean & Std. Deviation \\
\hline $\begin{array}{l}\text { Memiliki peralatan yang diproteksi dengan hak paten } \\
\text { perusahaan }\end{array}$ & 3.3947 & .75479 \\
\hline $\begin{array}{l}\text { Kepemilikan peralatan membantu kami untuk meraih } \\
\text { keunggulan kompetitif }\end{array}$ & 3.7105 & .56511 \\
\hline $\begin{array}{l}\text { Tingkat adopsi teknologi proses dalam perusahaan anda } \\
\text { dibandingkan dengan kompetisi industri pada basis global }\end{array}$ & 3.7105 & .56511 \\
\hline Peralatan produksi anda relatif terhadap industri. & 3.4211 & .79293 \\
\hline Kepemilikan alat dan teknologi & 3.5592 & .44049 \\
\hline
\end{tabular}

\section{Pengaruh Pembelajaran Internal dan Eksternal terhadap Tingkat Kepemilikan Peralatan dan Teknologi}

Tabel 7 dan 8 berikut menyajikan ringkasan hasil regresi berganda dan regresi sederhana untuk melihat Pengaruh Pembelajaran Internal dan Eksternal terhadap tingkat kepemilikan peralatan dan teknologi serta melihat pengaruh tingkat kepemilikan peralatan dan teknologi terhadap kinerja. Beberapa hal penting yang perlu dikemukakan mengenai pengaruh pembelajaran internal dan eksternal terhadap tingkat kepemilikan peralatan dan teknologi: Pertama, secara keseluruhan, hasil regresi berganda menunjukkan bahwa secara simultan variabel bebas pembelajaran internal dan pembelajaran eksternal menjelaskan $25.9 \%$ varian kepemilikan peralatan dan teknologi. Kedua, pembelajaran internal dan pembelajaran eksternal berpengaruh positif terhadap kepemilikan peralatan dan teknologi. Hal ini mengindikasikan bahwa kepemilikan peralatan dan teknologi dipengaruhi oleh tinggi rendahnya tingkat pembelajaran internal maupun eksternal organisasi. Dari temuan ini mengindikasikan bahwa hipotesis pertama penelitian ini diterima.

Tabel 7: Pengaruh Pembelajaran Internal dan Eksternal terhadap Tingkat Kepemilikan Peralatan dan Teknologi

\begin{tabular}{|l|l|l|l|l|l|l|l|l|}
\hline Dep Var & Parameter & B & SE & T & Sig & F & Sig & R2 \\
\hline \multirow{3}{*}{ KPA } & intercept & 1.960 & .202 & 9.723 & .000 & 34.476 & .000 & .259 \\
\cline { 2 - 7 } & L & .128 & .046 & 2.788 & .006 & & & \\
\cline { 2 - 6 } & EL & .348 & .068 & 5.089 & .000 & & & \\
\hline
\end{tabular}

Tabel 8 berikut menyajikan ringkasan hasil regresi sederhana untuk melihat tingkat kepemilikan peralatan dan teknologi terhadap kinerja. Beberapa hal penting yang perlu dikemukakan mengenai Hal ini antara lain: Pertama, secara keseluruhan, hasil regresi berganda menunjukkan bahwa secara simultan variabel bebas kepemilikan peralatan dan teknologi menjelaskan $31.6 \%$ varian kinerja operasional perusahaan. Kedua, kepemilikan 
peralatan dan teknologi berpengaruh positif terhadap kinerja operasi. Hal ini mengindikasikan bahwa kepemilikan peralatan dan teknologi mempengaruki baik buruknya kinerja operasi yang dapat dicapai oleh organisasi. Dari temuan ini mengindikasikan bahwa hipotesis kedua penelitian ini diterima.

Tabel 8: Pengaruh Tingkat Kepemilikan Peralatan dan Teknologi Terhadap Kinerja

\begin{tabular}{|l|l|l|l|l|l|l|l|l|}
\hline Dep Var & Parameter & B & SE & T & Sig & F & Sig & R2 \\
\hline Kin & intercept & 1.147 & .323 & 3.554 & .000 & 91.309 & .000 & .316 \\
\hline & Kap & .881 & .092 & 9.556 & .000 & & & \\
\hline
\end{tabular}

\section{Pengaruh Moderasi Strategi Manufaktur}

Sebelum mendiskusikan pengaruh moderasi strategi manufaktur, perlu dipahami terlebih dahulu mengenai strategi manufaktur yang diprioritaskan oleh perusahaan manufaktur di Indonesia. Hasil studi ini menunjukkan bahwa strategi biaya mendapat prioritas utama dibanding ketiga strategi lainnya, sementara itu strategi delivery mendapat prioritas yang paling akhir. Prioritas kepada strategi biaya menunjukkan kalau perusahaan-perusahaan manufaktur di Indonesia lebih berorientasi pada jangka pendek. Ini mungkin terkait dengan skenario ekonomi Indonesia yang baru berusaka bangkit dari dampak krisis global yang baru terjadi. Kondisi ini tampak berbeda dengan temuan di negara berkembang lain seperti India, Turki dan Brazil dan Hungaria yang sudah lebih memprioritaskan strategi fleksibilitas (Burgess, dkk. 1998; Dangayah dan Deskhmuk, 2000). Tabel 9 menunjukkan hasil selengkapnya penerapan strategi manufaktur.

Tabel 9: Statistik Diskriptif Strategi Manufaktur

\begin{tabular}{|l|r|r|}
\hline Strategy Manufaktur & Mean & Standard Deviation \\
\hline Menurunkan kos per unit & 4.3158 & .66191 \\
\hline Menurunkan kos material & 4.3158 & .84166 \\
\hline Mengurangi kos persediaan & 4.1316 & .74148 \\
\hline Strategi Biaya & $\mathbf{4 . 2 5 4 4}$ &. $\mathbf{6 4 5 7 7}$ \\
\hline Menurunkan tingkat produk cacat & 4.2368 & .79403 \\
\hline Menerapkan program pengendalian kualitas & 3.7105 & .80229 \\
\hline Memperbaiki kualitas pemasok & 4.1053 & .76369 \\
\hline Memperoleh sertifikasi tingkat nasional & 3.8974 & .95265 \\
\hline Memperoleh sertifikasi kualitas tingkat lokal & 3.6316 & 1.12517 \\
\hline Strategi Kualitas & $\mathbf{3 . 9 1 5 8}$ & .70309 \\
\hline Menurunkan procurement lead time & 3.6053 & 1.0277 \\
\hline Menurunkan waktu pengembangan produk baru & 3.6316 & .91300 \\
\hline Menurunkan tenggang waktu pabrikasi & 3.4474 & .89132 \\
\hline Menurunkan waktu set up & 3.5789 & .88932 \\
\hline Strategi Fleksibilitas & $\mathbf{3 . 5 6 5 8}$ & .69429 \\
\hline Memperbaiki layanan sebelum penjualan & 3.8158 & .72987 \\
\hline Meningkatkan kecepatan penghantaran & 3.8684 & .84377 \\
\hline Meningkatkan keandalan penghantaran & 3.8158 & 1.0097 \\
\hline Memperbaiki layanan sebelum penjualan & 3.7368 & 1.0574 \\
\hline Memperbaikilayanan teknis pada pelanggan & 3.8421 & .97333 \\
\hline Strategi Delivery & $\mathbf{3 . 8 4 1 5}$ & .74740 \\
\hline
\end{tabular}

\section{Pengaruh Moderasi Cost Strategy}

Berkenaan dengan peran moderasi strategi biaya terhadap hubungan kepemilikan peralatan produksi dan kinerja, temuan berikut ini perlu digarisbawahi: (1). Strategi biaya memoderasi pengaruh kepemilikan peralatan produksi dan tekonologi terhadap kinerja operasi (Tabel 10). (2). Pada level kepemilikan peralatan produksi rendah sampai moderate, 
pengaruh peralatan produksi nampak pada perusahaan yang menekankan pada strategi biaya, (3). Sebaliknya, pada level kepemilikan peralatan moderate-tinggi, pengaruh kepemilikan teknologi lebih besar pada perusahaan yang kurang menekankan pada strategi biaya. Diantara perusahaan yang memumpukan pada strategi biaya, investasi pada teknologi (Teknologi dan praktek manajemen modern) bukan menjadi suatu prioritas, karena ini hanya dianggap meningkatkan biaya operasi. Oleh karena itu diantara perusahaan yang bersedia melakukan investasi teknologi berarti mereka kurang menumpukan pada strategi biaya. Temuan ini konsisten dengan Lidman, dkk (2001) yang mengemukakan bahwa jika strategi biaya menjadi tumpuan atau prioritas perusahaan maka perusahaan akan mengurangi semua biaya yang terkait dengan biaya aktivitas operasional.

Table 10: Pengaruh Moderasi Cost Strategy

\begin{tabular}{|c|c|c|c|}
\hline \multirow[t]{2}{*}{ Variabel } & Step 1 & Step 2 & Step 3 \\
\hline & \multicolumn{3}{|c|}{ Standardized Beta } \\
\hline KPA & $.562^{* * *}$ & $.563^{* * *}$ & $1.076^{* * *}$ \\
\hline $\cos$ & & -.024 & -.444 \\
\hline $\mathrm{KPA} \times \mathrm{COS}$ & & & $-1.728^{* * *}$ \\
\hline $\mathrm{R}^{2}$ & .316 & .316 & .326 \\
\hline$R^{2}$ change & .316 & .001 & .010 \\
\hline F change & 91.309 & .169 & 2.987 \\
\hline & .000 & .681 & .088 \\
\hline \multicolumn{2}{|c|}{$* * *$ : significant at 0.01} & ant at 0 & significan \\
\hline
\end{tabular}

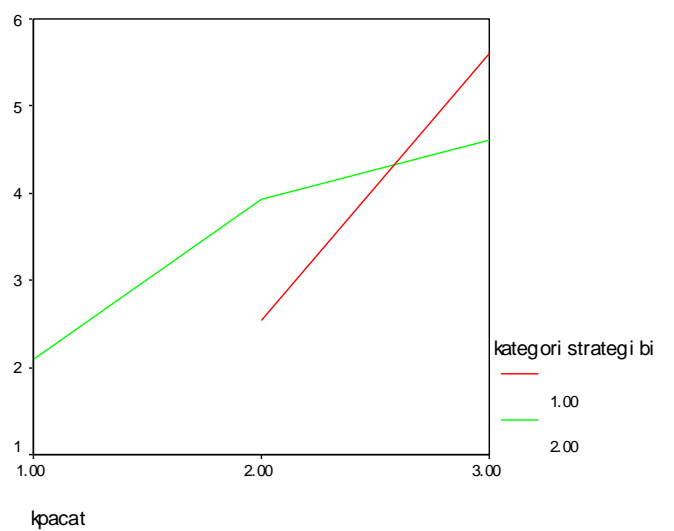

Gambar 1:

Pengaruh Moderasi Strategi Biaya terhadap Hubungan Kepemilikan Peralatan Teknologi dan Kinerja

\section{Pengaruh Moderasi Quality Strategy}

Tabel 11 menunjukkan peran strategi kualitas terhadap hubungan kepemilikan peralatan produksi dan kinerja operasi. Berkenaan dengan peran moderasi strategi kualitas terhadap peralatan produksi dan kinerja, temuan berikut ini perlu digarisbawahi: (1). Strategi kualitas memoderasi pengaruh peralatan produksi terhadap kinerja. (2). Pada level kepemilikan peralatan produksi rendah sampai moderate, pengaruh peralatan produksi nampak pada perusahaan yang menekankan pada strategi kualitas, (3). Sebaliknya, pada level kepemilikan peralatan moderate-tinggi, pengaruh kepemilikan teknologi lebih besar pada perusahaan yang kurang menekankan pada strategi kualitas.

Teknologi memungkinkan peningkatan efisiensi dan produktivitas fungsi operasi, sehingga akan meningkatkan kinerja manufaktur dan finansial. Saat teknologi didukung dengan strategi kualitas, produk yang dihasilkan akan lebih kompetitif dan semua aktivitas yang 
tidak memberikan nilai tambah seperti defects, reworks, dan scrap dapat dikurangi, sehingga akan mengurangi biaya produksi. Oleh karena itu penekanan pada strategi kualitas lebih jauh akan meningkatkan dampak teknologi terhadap kinerja. Temuan studi ini didukung oleh Butcher dkk. (1999), yang menemukan bahwa adopsi AMT (CNC, CAD, LAN, and CIM dan seriring dengan menumpukan pada strategi kualitas, fleksibilitas, dan penghantaran akan meningkatkan daya saing melalui perbaikan proses produksi, pengendalian kualitas, meningkatkan kapasitas, memperbaiki kualitas, dan menurunkan lead time. Temuan ini selaras dengan Tan dkk. (2000) di mana perusahaan dengan penekanan yang besar pada strategi kualitas cenderung mengadopsi praktik-praktik management kualitas (TQM dan TPM) pada tahap yang lebih tinggi dan menerapkan pembelajaran internal lebih serius.

Table 11: Pengaruh Moderasi Quality Strategy

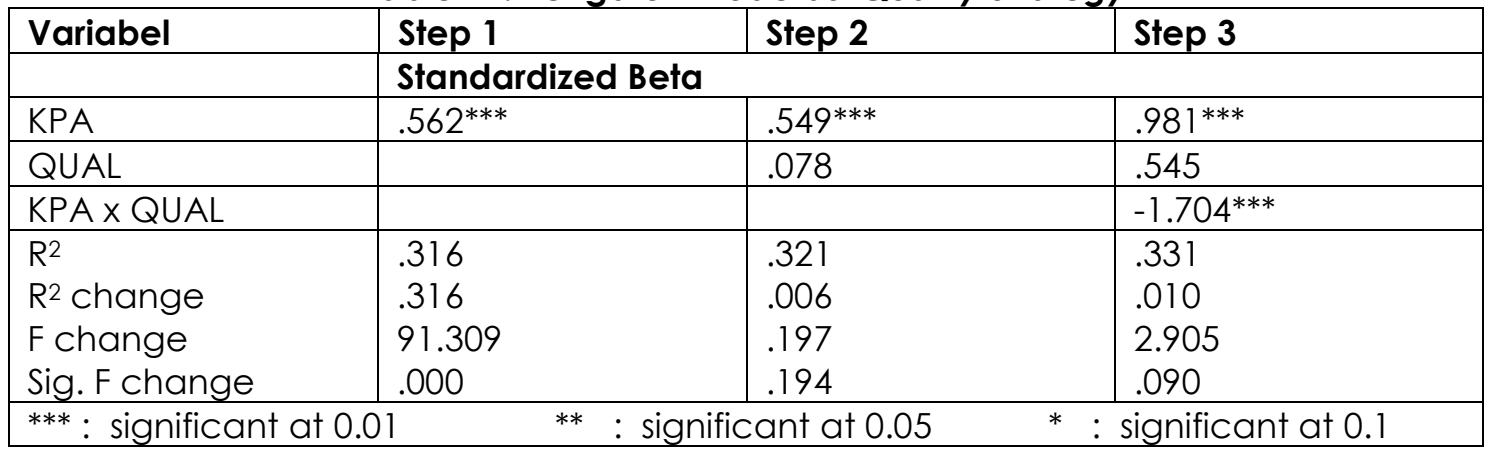

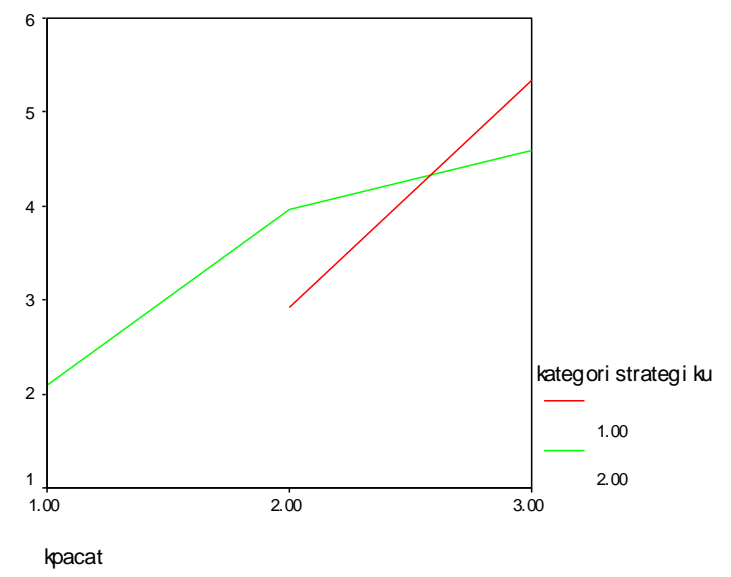

Gambar 2:

Pengaruh Moderasi Strategi Kualitas terhadap Hubungan Kepemilikan Peralatan Teknologi dan Kinerja

\section{Pengaruh Moderasi Flexibility Strategy}

Tabel 12 menampilkan hasil moderated regression yang menganalisis moderating effect strategi flexibilitas terhadap hubungan kepemilikan peralatan produksi dan teknologi dengan kinerja operasi. Nilai $\mathrm{R}^{2}$ change dan the F-change dari tahap 1 ke 2 dan dari tahap 2 ke 3 adalah significant, yang mengindikasikan bahwa strategy flexibilitas mempengaruhi hubungan kepemilikan alat produksi dengan kinerja kinerja. Hal ini lebih jauh ditunjukkan oleh fakta bahwa interaction term dalam model memiliki nilai standardized beta yang signifikan.. Strategi fleksibilitas memfokuskan pada usaha memenuhi permintaan pelanggan baik dalam bentuk volume maupun variasi produk. Dalam lingkungan bisnis dang sangat 
cepat berubah, strategi ini semakin berperan penting. Strategi fleksibilitas perlu di dukung dengan teknologi yang canggih seperti robotics automation, dan flexible manufacturing systems (FMS). Jadi, tersedianya teknologi canggih tanpa adanya strategi fleksibilitas adalah mismatch dan ini akan tercermin pada rendahnya kinerja dari semua dimensi. Temuan studi ini selaras dengan penelitian yang dilakukan oleh Gerwin (1993) dan Beach dkk. (2001). Gerwin (1993) menyatakan bahwa dengan memberikan tumpuan yang tinggi pada strategi fleksibilitas dan mengadopsi technology canggih akan menghasilkan kinerja manufaktur lebih baik. Beach dkk. (2001) menemukan fakta bahwa teknologi dan infrastruktur memiliki hubungan positif dengan teknologi, oleh karena itu dampak teknologi terhadap kinerja adalah lebih besar ketika perusahaan memberikan tumpuan yang lebih besar pada fleksibilitas sebagai prioritas kompetitif.

Tabel 12: Pengaruh Moderasi Flexibility Strategy

\begin{tabular}{|c|c|c|c|}
\hline Variabel & Step 1 & Step 2 & Step 3 \\
\hline & \multicolumn{3}{|c|}{ Standardized Beta } \\
\hline KPA & $.562^{* * *}$ & $.509^{* * *}$ & $.963^{* * *}$ \\
\hline FLEKS & & $.406^{*}$ & .661 \\
\hline KPA $\times$ FLEKS & & & $.808^{*}$ \\
\hline $\mathrm{R}^{2}$ & .316 & .334 & .345 \\
\hline$R^{2}$ change & .316 & .018 & .011 \\
\hline F change & 91.309 & .197 & .196 \\
\hline \multirow{2}{*}{\multicolumn{2}{|c|}{\begin{tabular}{l|l} 
Sig. $\mathrm{F}$ change & .000 \\
$* * *$ & : significant at 0.01
\end{tabular}}} & .021 & .068 \\
\hline & & ant at 0 . & significo \\
\hline
\end{tabular}

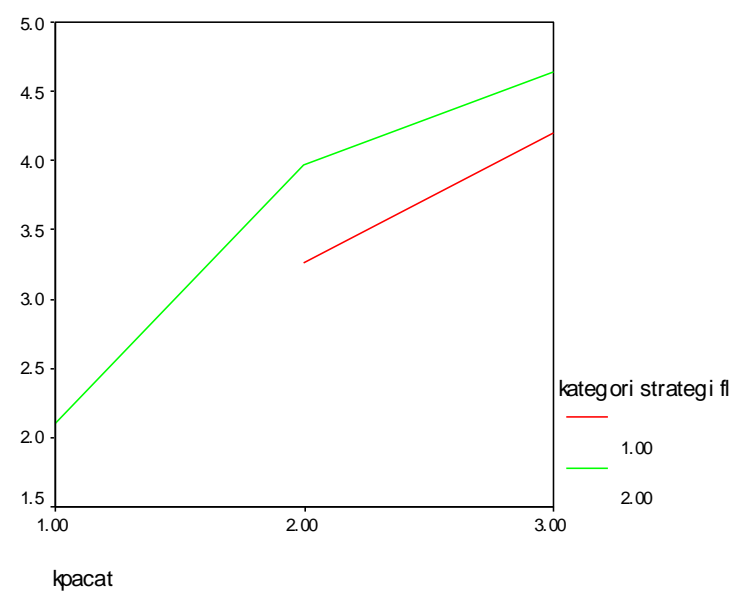

Gambar 3:

Pengaruh Moderasi Strategi Fleksibilitas terhadap Hubungan Kepemilikan Peralatan Teknologi dan Kinerja

\section{Pengaruh Moderasi Delivery Strategy}

Berkenaan dengan peran moderasi strategi penghantaran terhadap hubungan kepemilikan alat produksi dan kinerja (Tabel 13), studi ini menunjukkan strategi delivery tidak memoderasi pengaruh kepemilikan alat produksi dan teknologi terhadap kinerja operasi. Temuan ini bertentangan dengan beberapa hasil studi terdahulu yang dilakukan oleh Schroeder, dkk. (1995), Schroeder dkk.(2000), serta Cagliano \& Spina (2000) yang semunya mengemukakan bahwa melalui alignment antara technologi and strategi menghasilkan pay-off yang maksimal akan tercapai. 
Table 13: Pengaruh Moderasi Delivery Strategy

\begin{tabular}{|l|l|l|l|}
\hline Variabel & Step 1 & \multicolumn{2}{l|}{ Step 2 } \\
\hline & \multicolumn{1}{l|}{ Standardized Beta } \\
\hline KPA & $.562^{* * *}$ & $.535^{* * *}$ & $.872^{* * *}$ \\
\hline DEL & & .096 & .430 \\
\hline KPA x DEL & & & -.542 \\
\hline$R^{2}$ & .316 & .324 & .330 \\
$R^{2}$ change & .316 & .008 & .005 \\
F change & 91.309 & .197 & .198 \\
Sig. F change & .000 & .117 & .210 \\
\hline$* * *:$ significant at 0.01 & $* * \quad:$ significant at 0.05 & $*$ : significant at 0.1 \\
\hline
\end{tabular}

\section{SIMPULAN DAN SARAN}

\section{Ringkasan Temuan Utama}

Dari hasil pengujian hipotesis maka beberapa temuan utama dipaparkan dalam bagian ini. Pertama, pembelajaran internal berpengaruh positif terhadap kinerja, mengindikasikan bahwa kepemilikan alat dan teknologi didorong atau dapat ditingkatkan dengan meningkatkan proses pembelajaran internal. Temuan utama kedua studi ini mengindikasikan bahwa pembelajaran eksternal akan mendorong perusahaan untuk meningkatkan kepemilikan peralatan dan teknologinya. Ketiga, temuan studi ini menunjukkan bahwa kepemilikan peralatan dan teknologi mempengaruhi kinerja operasional.

Keempat, terkait dengan pengaruh moderasi strategi manufaktur. Pengaruh moderasi strategi biaya. Pengaruh kepemilikan teknologi akan lebih besar bagi perusahaan yang kurang menekankan pada strategi biaya, sebaliknya pengaruh kepemilikan teknologi terhadap kinerja ini lebih rendah jika perusahaan menekankan pada strategi biaya. Temuan studi ini menunjukkan bahwa dampak kepemilikan teknologi terhadap kinerja operasi dimoderasi oleh strategi biaya. Advanced technologies memerlukan biaya investasi yang tinggi, ini bertentangan dengan strategi perusahaan yang menekan biaya serendah mungkin untuk operasi. Hal dapat menjadi alasan mengapa strategi biaya tidak memoderasi hubungan antara teknologi dan kinerja.

Peran moderasi strategi kualitas. (1). Strategi kualitas memoderasi pengaruh peralatan produksi terhadap kinerja. (2). Pada level kepemilikan peralatan produksi rendah sampai moderate, pengaruh peralatan produksi nampak pada perusahaan yang menekankan pada strategi kualitas, (3). Sebaliknya, pada level kepemilikan peralatan moderate-tinggi, pengaruh kepemilikan teknologi lebih besar pada perusahaan yang kurang menekankan pada strategi kualitas. Teknologi memungkinkan peningkatan efisiensi dan produktivitas fungsi operasi, sehingga akan meningkatkan kinerja manufaktur dan finansial. Saat teknologi didukung dengan strategi kualitas, produk yang dihasilkan akan lebih kompetitif dan semua aktivitas yang tidak memberikan nilai tambah seperti defects, reworks, dan scrap dapat dikurangi, sehingga akan mengurangi biaya produksi. Oleh karena itu penekanan pada strategi kualitas lebih jauh akan meningkatkan dampak teknologi terhadap kinerja.

Peran moderasi strategi fleksibilitas. Strategi fleksibilitas memoderate pengaruh AMT dan SDM terhadap profitabilitas serta kinerja operasional. Bila dilihat secara seksama pengaruh AMT terhadap kedua indikator kinerja ini akan meningkat dengan prioritas perusahaan pada strategi flexibilitas, dan sebaliknya pengaruh SDM akan menurun terhadap ketiga indikator tersebut. Strategi flexibilitas memoderate hubungan sumber daya dengan pertumbuhan pertumbuhan profitabilitas. Jika diteliti strategi fleksibilitas cenderung menurunkan pengaruh sumber daya terhadap pertumbuhan profitabilitas, kecuali pada sumber daya material. Strategi flexibilitas menurunkan pengaruh material resources dan management practices terhadap pertumbuhan kinerja operasi, tetapi meningkatkan 
pengaruh SDM. Hal terakhir yang bias diamati dari peran stategi fleksibilitas adalah perannya dalam memoderasi sumber daya dan kinerja keseluruhan. Strategi ini menurunkan pengaruh AMT dan manajemen practices terhadap kinerja keseluruhan, meningkatkan pengaruh SDM terhadap kinerja keseluruhan, dan tidak memoderasi pengaruh sumber daya alam terhadap kinerja.

Peran Moderasi Strategi Delivery. Strategi delivery memoderasi pengaruh semua faktor sumber daya terhadap profitabilias dan kinerja operasi. Hanya saya dampak moderasi negatif terjadi pada pengaruh AMT dan sumber daya alam, dan moderasi positif terlihat pada pengaruh SDM dan management practices. Strategi delivery hanya memoderasi secara positif pengaruh sumberdaya manusia terhadap pertumbuhan profitabilitas. Strategi delivery memoderasi secara positif pengaruh SDM serta memoderasi secara negatif faktor sumber daya material terhadap pertumbuhan kinerja operasional. Akhirnya dapat dilihat pula bahwa strategi penghantaran memoderasi hubungan sumber daya (kecuali manajement practices) dan kinerja keseluruhan. Pengaruh AMT dan sumber daya material terhadap kinerja keseluruhan akan lebih rendah pada perusahaan yang memprioritaskan stategi penghantaran, hal sebaliknya terjadi ketika perusahaan menekankan atau memprioritaskan pada strategi fleksibilitas maka akan meningkatkan pengaruh SDM terhadap kinerja.

\section{Implikasi Hasil Penelitian}

Studi ini memiliki implikasi teoritis maupun manajerial. Secara teoritis studi ini mendukung resources-based theory yang digunakan sebagai dasar teori mengenai hubungan teknologi dan kinerja. Kepemilikan peralatan produksi dan teknologi terbukti merupakan resources dan capabilities yang dapat digunakan untuk meraih keunggulan kompetitif. Temuan studi ini menambahkan body of literature mengenai pentingnya pembelajaran internal dan dan eksternal dalam mengembangkan kapabilitas perusahaan manufaktur terutama di negara berkembang. Studi ini merupakan langkah awal untuk melakukan pengembangan studi empiris dengan mempertimbangkan lebih jauh faktor-faktor yang menentukan keberhasilan dalam pengelolaan sumber daya dan teknologi terutama melalui pembelajaran organisasi. Selanjutnya temuan studi ini juga mengindikasikan faktor strategi operasi yang memoderasi kepemilikan alat dan teknologi perusahaan terhadap kinerja. Penelitian ini juga memberikan implikasi manajerial antara lain (1). Menunjukkan bahwa proses pembelajaran organisasi penting untuk meningkatkan kapabilitas operasi terutama pada sektor manufaktur di Indonesia. (2). Perusahaan harus menyelaraskan kepemilikan peralatan dan teknologi dengan strategi operasi yang diterapkan untuk mencapai kinerja yang maksimal.

\section{Keterbatasan dan Saran}

Walapun demikian, penulis mengakui bahwa studi ini masih banyak memiliki keterbatasan. Hasil studi ini tidak dapat di generalisasi mengingat penelitian ini hanya dilakukan pada satu titik waktu tertentu di Indonesia dan data yang digunakan hanya merupakan persepsi CEO. Oleh karena itu peneliti menyarankan perlu dilakukannya longitudinal study. Melibatkan muliple-respondents dalam satu perusahaan akan menambah keakuratan hasil (Misalnya dengan memperhitungkan persepsi dari bidang operasional/manufaktur). Di samping itu studi kepemilikan peralatan dan teknologi pada perusahaan manufaktur diakui banyak mengalami bias jika persepsi terhadap tingkat kepemilikan peralatan dan teknologi,strategi manufaktur dan kinerja operasi berbeda-beda.

Data dikumpulan berdasar persepsi responden, self-rating, dan multi-choice questionnaire. Pendekatan ini memang memadai untuk memperoleh banyak informasu dalam waktu yang relative singkat. Semestinya dipertimbangkan untuk mengakukan studi yang sifatnya longitudinal, namun sayangnya hal ini belum dapat dilakukan dalam scope studi ini. Kuesioner yang ditujukan kepada pimpinan perusahaan, sehingga hanya pimpinan yang merespon semua pertanyaan yang terkait dengan pembelajaran internal, pembelajaran 
eksternal, kepemilikan peralatan dan teknologi serta kinerja operasi. Dalam hal ini sangat berpotensi untuk menimbulkan terjadiny mono-response bias. Keterbatasan terkait hal ini apakah manajer operasi, atau manajer-manajer lain yang terlibat dalam proses pembelajaran organisasi, pelaksanaan strategi, dan capaian kinerja operasi memiliki persepsi yang sama dengan pimpinan perusahaan. Namun demikian memang pimpinan perusahaan dipilih sebagai target subject karena dianggap memiliki akses informasi terhadap semua variable yang menjadi focus of interest dalam penelitian ini.

Akhirnya peneliti memberikan beberapa saran untuk penelitian-penelitain yang akan datang yang dapat dilakukan untuk memperdalam studi tentang firm's resources: (1). Studi ini dapat dilakukan juga di negara berkembang lain yang memiliki kultur yang hampir sama. (2). Instrument yang sama dapat juga digunakan untuk meneliti adopsi teknologi pada perusahaan kecil dan sedang. (3). Melakukan studi tentang pembelajaran organisasi dengan mempertimbangkan variabel-variabel lingkungan bisnis, konteks organisasi dan kultur sebagai moderator dalam mempengaruhi hubungan pembelajaran organisasi dankinerja, akan semakin memperkaya pengetahuan dan wawasan mengenaipengelolaan sumber daya perusahaan.

\section{DAFTAR PUSTAKA}

Alegre, J., Chiva, R., 2008. Assessing the Impact of Organizational Learning Capability on Product Innovation Performance: an Empirical Test, Technovation, 28, 315-326.

Almeida, P., Dokko, G., dan Rosenkopf, L., 2003. Startup Size and The Mechanism of External Learning: Increasing Opportunity and decreasing Ability. Research Policy, 32, 301-305.

Anatan, L., 2007. Knowledge Transformation In Innovation Strategy Implementation. Management Forum Prasetya Mulya Business School, 1 (2), 45-60.

Anatan, L. 2007. The Determination of Competitive Priorities in Manufacturing and Service Firms: A Resource Based View. Research Report. LPPM, Maranatha Christian University.

Buffa, E.S. (1984). Making American manufacturing competitive. California Management Review, 26, Spring, 24-46.

Bruton, G. D., Lohrke, F. T., dan LU, J. W., 2004. The Evolving Definition of What Comprises International Strategic Management Research. Journal of International Management, 10, 413-429.

Burgess, T.F. Gules, H.K. Gupta, J.N.D., \& Tekin, (1998). Competitive priorities, process innovations and time based competition in the manufacturing sectors of industrializing economies: the case of Turkey. Benchmarking for Quality Management and Technology, 5(4), pp. 304-316.

Calantone, R. J., Cavusgil, S. T., dan Zhao, Y., 2002. Learning Orientation, Firm Innovation Capability, and Firm Performance. Industrial Marketing Management, 31: 515-524.

Cagliano, R \& Spina, G., 2000. How Improvement Programs Of Manufacturing Are Selected: The Role Of Strategic Priorities And Past Experience. International Journal of Production and Operation Management, Vol. 20 (7), pp. 772-791.

Chuang, S.H., 2004. A Resource-based view on Knowledge manufacturing Capability dan Competitive advantage: An Empirical Investigation, 27, 459-465.

Currie, W.L. \& Seddon, J.M. (1992). Managing AMT in a just in time environment in the UK and Japan. British Journal of Management, 3, 123-136.

Corbert, C. \& Van, W. (1993). Trade-offs? What trade-offs? Competence and competitiveness in manufacturing strategy. California Management Review, 35 (4), 107-120. 
Dean, J.W. \& Snell, S.A. (1991). Integrated manufacturing and job design: moderating effects of organizational inertia. Academy of Management Journal, 34(4), 776-804.

Dean, J.W. \& Snell, S.C. (1996). The strategic use integrated manufacturing: an empirical examination. Strategic Management Journal, 17, 459-480.

Ellitan, L. 1998. Pengaruh Sumber keunggulan Kompetitif Terhadap Kinerja Industri Manufaktur di Indonesia, Thesis, Universitas Gadjah Mada, Tidak Dipublikasikan.

Ellitan, L., Jantan, M, \& Dahlan, N. (2001). Technology Adoption In Indonesian Manufacturing Firms: A case Study, The Fourth Asian of Academy Management Conference Proceedings, 1(1), 357-362.

Ellitan, L. 2002. Technology Adoption, technology management and manufacturing performance: a case study from Indonesia, Journal of Business and Accounting, Faculty of Economic, Trisakti University, Jakarta ,pp 1-21.

Ellitan, L. 2003. Peran Sumber daya dalam Meningkatkan Pengaruh Teknologi Terhadap Produktivitas, Jurnal Manajemen dan Wirausaha, Vol 5 no. 2. Universitas Kristen Petra, Surabaya, September, pp. 155-170.

Ellitan, L. 2004. Implementation of Advanced Manufacturing Technologies: Expected Benefit Vs Anticipated Risks, Matrix: Jurnal Teknik Industri dan Produksi, Vol 1, no. 2, pp. 123131.

Ellitan, L. 2005. Adopsi Teknologi dan Fleksibilitas Manufaktur: Peran Sumberdaya Sebagai Moderator, Jurnal Manajemen Maranatha, Vol 5 November, pp. 13-34.

Ellitan, 2006. Teknik Perbaikan terus-menerus (continuous improvement techniques), pentingnya partnership dan pengaruhnya terhadap kinerja operasional perusahaan, Jurnal Widya Manajemen Akuntansi, April, 2006.

Gordon, G \& Sohal, A.S. (2001). Assessing manufacturing plant competitiveness: an empirical field study. International Journal of Operation and Production Management, 21 (1/2), 233-253.

Hair, J.F., Anderson, R.L., Tatham, dan W.C., Black, 1988. Multivariate Data Analysis, $5^{\text {th }}$ ed., Upper Saddle River, New Jersey, Prentice Hall, Inch.

Hart, S.L., 1995. a Natural Resources-Based View Of The Firm. Academy Of management Review. Vol. 20, No.4, pp. 986-1014.

Hayes, R.H., Pisano, G.P., 1994. Beyond The World Class: The New Manufacturing Strategy. Harvard Business Review 72 (1), pp. 77-84.

Hofer, C. dan Schendel, D., 1978. Strategy Formulation: Analitical Concept. St.Paul, MN. West.

Jaikumar, R. (1986). Postindustrial manufacturing, Harvard Business Review, 64(6). 69-76

Jiang, X., Li, Y., 2008. The relationship Beetwen Organizational Learving and Financial Performance in Strategic Alliance: A Contingency Approach. Journal of World Business, 43, 365-379.

Ko, E; Kincade, D. \& Brown, J.R. 2000. Impact of Business Type Upon The Adoption of Quick Response Technologies: The Apparel Industry Experience. International Journal of Production and Operation Management, vol. 20(7), pp. 772-791.

Liao, S.H., Fei, W.C., Liu, C.T., 2008. Relationship between Knowledge Inertia, Organizational Learning, and Organizational Innovation. Technovation, 28, 183-195.

Paiva, E.L., Roth, A.V., Fensterseifer, J.E., 2008. Organizational Learning Capability on Product Innovation Performance: An Empirical Test. Technolovation, 28, 315-326.

Porter, M. 1980. Competitive Advantage Creating and Sustaining Superior Performance, New York: Free Press. 
Parthasarthy, R. \& Sethi, S.P. (1992). The impact of flexible automation on business strategy and organizational structure, Academy of Management Review, 17(1), 86-111.

Prieto, I. M., \& Revilla, E. 2006. Learning Capability and Business Performance: A non-Financial and Financial Assessment. The Learning Organization, 13(2): 166-185.

Schroeder,R.G., Bates, K.A., dan Junttila, M.A. (2002). A-Resource Based View Of Manufacturing Strategy And The Relationship To Manufacturing Performance. Strategic Management Journal,Vol. 23, pp. 105-117.

Skinner, W., 1969. Manufacturing- Missing Link in Corporate Strategy. Harvard Business Review, 47 (3), 136-145.

Swamidass, P.M., Newell, W.T., 1987. Manufacturing Strategy, Environmental Uncertainty and Performance: A Path Analytic Model. Management Science, 33 (4), 509-524.

Vernon, H., L.H. Wortzel, 1997. Strategic Management in A Global Economy. John Wiley and Sons Canada. 